\title{
Interaction Among Corporate Governance, Innovation, and Performance in Vietnam's Banking Sector
}

\author{
Quang Linh Huynh ${ }^{1}$, Huy Hoang Tran $^{2} \&$ Hong Anh Thi Nguyen ${ }^{3}$ \\ ${ }^{1}$ School of Economics \& Law, Tra Vinh University, Vietnam \\ ${ }^{2}$ Faculty of Finance \& Banking, University of Finance-Marketing, Vietnam \\ ${ }^{3}$ Faculty of Finance \& Banking, Industrial University of Ho Chi Minh City, Vietnam \\ Correspondence: Quang Linh Huynh, Associate Professor in School of Economics \& Law, Tra Vinh University, \\ Vietnam. E-mail: huynhquanglinh@tvu.edu.vn
}

Received: May 19, 2020

doi:10.5430/rwe.v11n5p235
Accepted: July 28, 2020

Online Published: September 3, 2020

URL: https://doi.org/10.5430/rwe.v11n5p235

\begin{abstract}
Background/Objectives: The current research tries to investigate effects of the three elements of corporate governance (chief executive officer duality, board independence and size) on banking performance and then analyze the mediating role of innovation on these effects, which are overlooked at Vietnamese banks.
\end{abstract}

Methods/Statistical analysis: The research sample for this research encompassed 78 usable firm-year observations of 25 publicly listed organizations in the banking sector on Vietnam's three main Stock Exchanges during a 4-year period from 2015 to 2018. To test out the causal hypotheses, the multiple linear regressions were carried out; while to statistically explore the mediating hypotheses, the approaches for testing the statistical significance of mediating effects, proposed by Aroian (1947) were applied.

Findings: The empirical findings disclose that good mechanisms of corporate governance in banking can lead to superior banking performance. The empirical results also discover that innovative activities in banking statistically interferes in the causal linkage between corporate governance and banking performance; where innovation fully interferes between the duality of management and banking performance, but it partially interferes in the relations of board independence and board size with banking performance.

Improvements/Applications: This research indicates that the banks, in which the positions of the director and chairperson are held by one separate person, may suffer agency costs, so achieve poorer banking performance. Therefore, the banks in Vietnam should assign the positions of the chief executive officer and chairperson to two separate individuals. The banks should hire more independent executives in the managerial board in order to lessen agency costs, so can get better banking performance. Moreover, the banks with larger managerial boards can improve banking performance since they possess better business experience, expertise, skill and other relations that can create substantial resources, so enhance banking success. It also shows that when included into the research model of corporate governance and banking performance, innovativeness in banking should be carefully considered, because it could interfere into this research model.

Keywords: performance, banking, corporate governance, innovation, Vietnam

\section{Introduction}

Recent research on corporate governance has remarkably increased due to its importance to organizational success (Abobakr, 2017). Corporate governance is critical due to the separation between ownership and administration in publicly listed firms (Fanta et al., 2013). Within organizations, shareholders (principals) delegate the rights to managers (agents) to make business decisions, requiring the agents to act in the greatest benefits for the principals. However, the "agency problem" occurs when the agents do not make their decision to the greatest benefits of the principal, but tend to be engaged in self-interest at the costs of shareholders. Wheelen et al (2010) regarded corporate governance as the bond among shareholders, managerial boards and the top director in determining the way and effectiveness of the organization. Furthermore, corporate governance is also referred to as the arrangements, processes, procedures and mechanisms, which are applied to direct and control firms in a way to improve long term benefits for shareholders through the accountability of directors and so boost organizational performance (Tomar \& 
Bino, 2012). With such arrangements, processes, procedures and mechanisms, the recognized agency problem, derived from the difference between ownership and administration leading to the conflicts of benefits among stakeholders, could be addressed such that the benefits between executives and their shareholders can be aligned. The previous studies have discussed a lot on the causal linkage from corporate governance to performance; but, only a few practical projects analyzed corporate governance in the banking sector (Muttakin \& Ullah, 2012).

The 2007-2008 monetary crises have again leaded to the disputes on the causal association from corporate governance to banking performance (Naushad \& Malik, 2015). In spite of its significance, this topic has been examined by only a little research. Besides, these projects were mostly performed in developed economies. Recently, just some attention to corporate governance in emerging economies has been paid (Abobakr \& Elgiziry, 2017). In developing economies, corporate governance faces various challenges such as low institutional ownership, centered ownership and underdeveloped finance markets (Latif et al., 2017); there is therefore a big need to carry out research on this field in those countries including Vietnam. Furthermore, very little has been considered for the banking sector, especially for Vietnam's banking sector. The banking sector in Vietnam has made considerable developments deriving from steady inflation and interest rate, positive business environment for direct investment from foreign and transformation from shortfall to superfluous of the nation's current account. Vietnam's banking sector has played a critical role in developing the national economy. In Vietnam, there exist two levels in the banking sector. Firstly, Vietnam's State bank is in charge of monetary policy as well as supervision/regulation of Vietnam's banking system. Secondly are commercial banks, financial institutes, people's credit funds, credit co-operatives as well as organizations of insurance.

The current research is targeted to study the causal link from corporate governance to banking performance in Vietnam as an emerging economy. Especially, it tries to mention and analyze innovativeness in banking which could affect the corporate governance-banking performance. Corporate governance has been widely documented a crucial trigger of innovative activities in banking that in turn results in better banking performance. The current study is expected to make some contributions to the contemporary knowledge of corporate governance that explains banking performance through innovative processes. This research is continuing in the following structure. 'Literature reviews and hypotheses' make the arguments to support the causal linkage from corporate governance to banking performance that is mediated by innovativeness in banking. Afterwards, the 'Research design' offers the guidance for measuring the variables and collecting the data, followed by the 'Empirical findings'. Ultimately, some discussions and conclusions will be made in the 'Discussions and conclusions'.

\section{Literature Review}

The sector of banking has made important contributions to the growth of every economy. Given that banks play the unique role in the payment system and financial intermediation, the collapse of them is able to destroy the economy such as the 2007-2008 global financial crises (Owino \& Kivoi 2016). A lot of policymakers reflect that the efficiency of banks can augment the competence of monitoring and ensure a sound financial system, which helps economic growth; yet, employing the mechanism of corporate governance to improve banking effectiveness has been still addressing considerable challenges because of the distinctive nature of the banking field. The structure of banking corporate governance has supposed sharp importance and has raised international concerns as it helps to improve the quality of services, leading to appropriate management in the activities of banking (Fidanoski et al., 2014). The intricate nature of banking may result in asymmetric routing that limits shareholders' monitoring the self-interest behaviors of banking managers (Jiang et al., 2012). Good mechanisms of corporate governance likely allow banks to alleviate the inconsistency of benefits among stakeholders, which is critical in lessening agency costs derived from the separation between ownership and administration, so improving competitive advantages for the banks. This will lead to sustainable economic development and banking performance for the banks.

Various theories concerning corporate governance have been developed on the nature and importance of corporate governance (Fanta et al., 2013). Agency theory is commonly regarded a tool of clearing up a variety of issues relevant to corporate governance, called the principal-agent theory. The principal-agent theory is commonly regarded as a starting point for any arguments related to corporate governance originating from the conventional view. The primary issue of agency in contemporary companies is mainly because of the separation between management and ownership. The contemporary companies are deemed to suffer from that separation. As a result, they are administrated by qualified directors who are not able to be monitored by separate shareholders. Agency theory recommends numerous mechanisms to lessen the agency issues within the organization. Encouraging mechanisms can be used to compensate managerial efforts of serving the principals' benefits. Dividend mechanisms diminish managerial intention to overinvest, which can be funded by internal free cash flows. Bonding mechanisms decrease 
managerial ethical risk that likely arises when they cannot be constrained by bond contract as well as bankruptcy risk (Sanda et al., 2005).

Stewardship theory anchored in sociology and psychology highlights that directors are not motivated by separate objectives but rather they are stewards, whose motivation is aligned with those of their owners (Davis et al., 2005), in contrast with agency theory asserting that the conflict of benefits between agents and principals is inevitable unless suitable mechanisms of management are applied to align these interests. The stewardship viewpoint proposes that stewards (executives) can be satisfied and motivated when firm effectiveness is achieved even at the cost of the stewards' own objectives (Abdullah \& Valentine, 2009). From the view of stewardship theory, directors behave in a manner to accumulate other values with the jobs such as a good reputation, rather than try to improve their worth. Stewards establish their strong duties and commitment to their organizations. Therefore, when the firm's objective is obtained, the benefits of stewards will be maximized.

Stakeholder theory has been more well-known as various studies have documented. Firms' behaviors influence organizational exterior environments requesting responsibility to broader stakeholders than only shareholders. In addition, McDonald and Puxty (1979) stated that, firms are not any more the tool of shareholders alone, but they operate within society. Consequently, they are supposed to be responsible to the whole society. It has been recognized economic value is produced by those that willingly work jointly to advance everyone's situation (Freeman et al., 2004). An extension of the stakeholder theory as a progressive one was suggested; but problems concerning the empirical test have restricted its importance (Sanda et al., 2005). The goal of a firm not only earns money to satisfy its investors and management, but also invariably learn suitable methods to balance the interests among its various stakeholders to guarantee every constituency can attain some extent of satisfaction for the benefits (Abrams, 1951).

Prior research stressed that, the positions of the chief executive officer and chairperson should be held by two individuals (Kang \& Zardkoohi, 2005). Duality is cleared as the appointment of the same individual holding both the chief executive officer and chairperson during the same period. As regards the banking industry, little research has analyzed the influence of duality on banking performance. As Pi and Timme (1993) discovered, the effectiveness of banking is lower due to the duality of management in banking. Really, a combined role of the chairperson and chief executive officer takes into account the better information of the actions and banking environment. The duality can enhance the capability and commitment of management to their banks, so resulting in higher banking effectiveness. They are aggravated to build up good reputation in the labor market. The duality has crucial costs that offset its possible profits for most big organizations. In fact, the position of the chief director of banks is tremendously important to pursue a strategy of rooting and to earn its rights.

Agency theory recommends a greater percentage of independent managers can improve banking performance because it can lessen the disagreement of interests between the principals and agents that makes administration more effective (Shleifer \& Vishny, 1997). Prior research discovers that the independence of boards is positively connected with banking performance (De Andres \& Vallelado, 2008). The role of managerial boards is largely dependent on the characteristics of these boards, which can influence banking performance (Johnson et al., 1996). Agency theory proposes a greater percentage of independent executives will augment the supervision and minimize self-interested behavior by directors; so can lead to improved banking performance.

A significant connection from board size to organizational performance has been found in previous studies. Lipton and Lorsch (1992) emphasized a bigger managerial board possibly will face bad coordination owing to a large number of possible exchanges among members. However, other researchers discovered a positive link from board size to banking performance (Adam \& Mehran, 2012; Dalton \& Dalton, 2005). Bigger managerial boards likely augment performance since they own necessary skills and knowledge (Setia-Atmaja et al., 2009). Consequently, board size is a vital force in addressing business decisions and banking performance. Additionally, by investigating the bond from board size to performance, Belkhir (2005) revealed evidence in contrast to previous theories that suggest smaller boards are more competent. Instead, this scholar discovered a positive connection from board size to banking performance. Overall, the aforementioned arguments can come to the following hypotheses.

H1: The duality of the chairperson and chief executive officer negatively affects banking performance

H2: The percentage of independent executives in the managerial board positively influences banking performance

\section{H3: The size of the managerial board positively affects banking performance}

On the one hand, there exists an influence of corporate governance on organizational performance, on the other hand a causal link from corporate governance to innovation has been well established, and furthermore, innovation is 
regarded as an important determinant of organizational performance (Nawaz Khan et al., 2019). Therefore, it had better take into account the interchange of innovation in the research model when analyzing the association from corporate governance to organizational performance. What is innovation derived from? The traditional literature of innovation had domination over the focus of managerial researchers on the link between innovative actions and market behavior and considered market structure as a set of connections of internal/external linkages among single coherent agents (Schumpeter, 1934). Contrastingly, Schumpeter (1942) had a tendency to concentrate enterprises as the explicit and enclosed carrier of the innovative dynamics. Furthermore, a recent managerial knowledge emphasizes the significant role of corporate governance for organizational performance, and focuses on the differences in diverse aspects of corporate governance which is recognized as a vital driver to innovative actions. These actions do not seem as an effect of maximizing organizational profits, but it comes out since stakeholders want to invest in innovation, which is determined by corporate governance structures (Belloc, 2012).

According to Miozzo and Dewick (2002), there is a limitation in the assessment of the connection from corporate governance to innovative activities as the chief theories of corporate governance have not explained the process of innovation methodically. These researchers emphasized the need for a clarification of the specific linkages between corporate governance and diverse actions of innovation at the joint research model. Furthermore, Distanont (2020) documented innovative activities as an imperative enabler for enterprises to earn profits and maintain their competitive advantages in business. Innovativeness not only fully exploits current resources and advance effectiveness, but also creates innovative intangible assets for enterprises because innovative enterprises are better in response to the needs of their customers, which brings out improved organizational performance for the enterprises (Sadikoglu \& Zehir, 2010) and enhances production quality (Parasuraman, 2010); so management researchers have increasingly focused on the influence of innovativeness on organizational performance (Vaccaro et al., 2010). Enterprises with more innovative research and development are likely more efficient in improving organizational performance than those with less innovative research and development (Singh, 2008).

The role of directorial boards is to shape various committees according to the skills and proficiency of members (Kiel \& Blennerhasett, 1984). In addition, Galia and Zenou (2018) highlighted that the size of managerial boards take an important role in improving innovative activities in business; whereas Nawaz Khan et al. (2019) argued numerous members in managerial boards mean there are a range of expertise which could allow the managerial boards to do their job better, so stimulate innovative actions that lead to good firm performance. Cheng (2008) found out that the size of managerial boards might trigger investments in innovation processes through research and development activities that could improve organizational performance, because a larger size of managerial boards is less likely related to high-risk activities. According to agency theory, various independent executives in managerial boards could enable enterprises to make better business decisions leading to better firm performance. The existing managerial knowledge indicates benefits that the independent executives bring about for enterprises. Therefore, enterprises should take on as many independent executives into managerial boards as possible (Daily \& Dalton, 1993). Additionally, Balsmeier et al. (2017) suggested the influence of independent directors in managerial boards on innovative activities of their enterprises. Grounded on regulatory alterations, they asserted enterprises with the majority of independent directors in managerial boards invest more on research and innovation because the independence of managerial boards is recognized as an important determinant in innovation processes. Moreover, Chung et al. (2002) discovered a positive causal link from innovative activities through research and development processes and organizational performance, however only for enterprises with the majority of independent executives in managerial boards.

Various researchers proposed enterprises should separate the functions of the chief executive officer and chairperson. In line with this perspective, Blibech and Berraies (2018) argued that the separation of the managerial roles enable enterprises to be able to control business decisions made by executives and reduces the inconsistency related to agency problems. The combination of the roles likely allows executives to be easy to support for their proposed projects although they do not make any profits for the enterprises (Fama \& Jensen, 1983). In agreement with this trend, Jermias (2007) also found out that the duality of managerial roles negatively affects innovative activities and organizational performance. Furthermore, Koo (2019) regarded the role of chief executive officers is a vital driver of innovation in business, because they are the main decision-makers who affect innovative activities, which then leads to better performance. Overall, the abovementioned discussions result in the summary where the chief executive officer duality, board independence and board size of corporate governance are vital determinants of innovative activities in business, which in turn lead to superior organizational performance. For the banking sector, there are numerous researchers who have discussed and explored the relationships among innovation, banking performance and corporate governance in which corporate governance augments innovative processes in banking then which 
leads to better banking performance (Abobakr, 2017; Abobakr \& Elgiziry, 2017; Adams \& Mehran, 2012; Belkhir, 2009; De Andres, \& Vallelado, 2008; Fanta et al., 2013; Fidanoski et al., 2014; Jiang et al., 2012; Kang \& Zardkoohi, 2005; Naushad \& Malik, 2015; Owino \& Kivoi, 2016; Pi \& Timme, 1993; Tomar \& Bino, 2012; Hassan, 2012; Shet, 2016; Sarkar, 2016; Rishi \& Saxena, 2004; Hassan et al. 2013; Lay Hong, 2016). Drawing on procedures stipulated by Baron and Kenny (1986) that suppose a three-variable model where two causal relationships exist (one of them is the direct impact of the explanatory variable on the explained variable and the other is the indirect impact through a third variable which is referred to as the mediating variable), this research suggests the mediating role of innovation in the causal link from the variables of corporate governance to banking performance. It could then posit the following hypotheses.

\section{H4: The causal link from chief executive officer duality to banking performance is mediated by innovation}

H5: The causal link from board independence to banking performance is mediated by innovation

H6: The causal link from board size to banking performance is mediated by innovation

\section{Research Design}

Corporate Governance is measured with the duality of the chairperson and chief executive officer (CE1), the percentage of independent executives in the managerial board (CE2) and the size of the managerial board (CE3). CE1 is considered 1, where the chief executive officer and chairperson is the same person, otherwise $=0$. CE2 is calculated by dividing the number of independent executives by the total amount of members in the managerial board. CE3 is measured by summing up the total amount of members in the managerial board. These measurements are adapted from Wang and Huynh (2014) and Naushad and Malik (2015). Banking performance is measured with the value of ROA (BE), which is get after dividing the operating income by the total assets for each bank. This measurement is adapted from Naushad and Malik (2015). Innovation (INV) is adapted from Nawaz Khan et al. (2019) who modified the scale from Darroch and Jardine (2002). This variable is composed of 11 dimensions (from INV1 to INV11) which are measured with a five-Likert scale. These 11 dimensions are (1) We have launched products or services that are the first of their kind in the world, (2) We often add new product or services to our existing ranges, (3) We have launched products or services for which this organization lacks the technological knowledge, (4) We often reposition existing products or services, (5) We often change the way we make or deliver products or services, (6) We develop products or services that will require consumers to substantially alter their behavior, (7) We often improve or revise existing products or services, (8) We develop product or services that offer greater advantages to consumers than any other product or service currently, (9) We develop products or services that better meet the needs of consumers than any other product or service currently available, (10) We have lunched products or services for which this organization lacks the business experiences or knowledge, and (11) We often introduce new ranges of products or services not previously offered by this company.

The research population of this project consisted of publicly listed banks on the three main Stock Exchanges in Vietnam, which were totally 25 banking organizations. Before collecting the data for the research analyses, a pilot test was performed for measurements with 20 directors involved in management to ensure that the measurements in the research model are valid and suitable (Blair \& Conrad, 2011). The sample size covered a 4-year period from 2015 to 2018 . With the 25 banking organizations, there were 85 suitable firm-year cases and only 78 usable firm-year observations. This number of observations satisfies the lowest limit of the research sample size suggested by Nunnally (1978). Vietnam was selected as a case study for the current study as it has been one of the fastest developing nations and a member of Southeast Asia. Additionally, as the third most populous Southeast Asian nation after the Philippines and Indonesia, Vietnam hopes to make gradually more contributions to the world. The active and fast changing business environment leads banks in Vietnam to pay more attention to efficient managerial mechanisms to maintain and develop sustainably.

\section{Empirical Findings}

The variable "innovation (INV)" encompassed 11 dimensions, so the dimensions of this variable were performed with reliability analyses for the reliability of the scale. The findings are shown in Table 1. At round 1, the total correlations of INV1, INV 10 and INV11 gain the values under 0.3, indicating no reliability for them in the scale. Therefore, these dimensions of INV1, INV 10 and INV11 were deleted from the scale of INV, which are (1) We have launched products or services that are the first of their kind in the world, (10) We have lunched products or services for which this organization lacks the business experiences or knowledge, and (11) We often introduce new ranges of products or services not previously offered by this company.

The remaining 9 dimensions continued to be entered into round 2 . All of the 9 item-total correlations exceed the 0.3 
value and the Cronbach's $\alpha$ if the dimension is removed are all less than their own Cronbach's $\alpha$ of 0.959 , which is greater than 0.7, the smallest level as Nunnally (1978) recommended. These abovementioned findings demonstrate the 11 dimensions meet the reliability. As a result, they should be retained for subsequent analyses. The 9 dimensions of INV2 to INV9 were averaged into INV, which was used for further steps.

The problem of multicollinearity makes the linear regression estimates inexact, so it is necessary to be tested. Multicollinearity exists in multiple linear regressions when two or more of the independent variables in the research model are closely related. Table 2 shows the correlations among the four independent variables used in the research, namely INV, CE1, CE2 and CE3. All of the correlations among these four variables are under 0.7, the greatest level stipulated by Nunnally (1978), indicating no multicollinearity occurs in the research model.

In order to test out the three causal hypotheses that state that the duality of the chairperson and chief executive officer (CE1), the percentage of independent executives in the managerial board (CE2) and the size of the managerial board (CE3) affect banking performance (BE), this research carried out the multiple linear regression (Model 1). The empirical findings are shown in Table 3, indicating that the three (3) variables of corporate governance explain $39.1 \%$ of variation in banking performance with $\mathrm{F}$ of 15.843 at the $1 \%$ significance level.

The duality of the chief executive officer and chairperson (CE1) negatively affects banking performance (BE), where the $\beta$ is -0.518 at the $5 \%$ significance level. The percentage of independent executives in the managerial board (CE2) positively influences banking performance (BE) with the $\beta$ of 0.391 at the $1 \%$ significance value; whereas the size of the managerial board (GE3) positively influences banking performance (BE) with the $\beta$ of 0.017 at the $1 \%$ significance level. Furthermore, the Durbin Watson statistic value is 2.263 , falling between dU to (4-dU), demonstrating that there is no autocorrelation in the multiple regressions. Those findings are all in support of Hypotheses 1 to 3, where the duality of the chairperson and chief executive officer, the percentage of independent executives in the managerial board as well as the size of the managerial board impose statistically significant influences on banking performance. Overall, it can recommend the duality of the chairperson and chief executive officer is the most imperative variable to banking performance at the -0.585 coefficient level; while the size of the managerial board plays the least important role in leading to improved banking performance with the 0.017 coefficient. The percentage of independent executives in the managerial board takes the second most important role in improving banking performance with the 0.391 coefficient. Therefore, the hypotheses H1 to H3 are supported.

Table 1 . Results for the validity and reliability

\begin{tabular}{|c|c|c|c|c|}
\hline Round & Dimension & Total Correlations & $\alpha$ if dimension removed & Cronbach's $\alpha$ \\
\hline \multirow{11}{*}{1} & INV1 & .091 & .899 & \multirow{11}{*}{.882} \\
\hline & INV2 & .851 & .856 & \\
\hline & INV3 & .781 & .860 & \\
\hline & INV4 & .867 & .855 & \\
\hline & INV5 & .777 & .861 & \\
\hline & INV6 & .851 & .856 & \\
\hline & INV7 & .781 & .860 & \\
\hline & INV8 & .867 & .855 & \\
\hline & INV9 & .813 & .859 & \\
\hline & INV10 & .175 & .905 & \\
\hline & INV11 & .052 & .909 & \\
\hline \multirow{9}{*}{2} & INV2 & .875 & .952 & \multirow{9}{*}{.959} \\
\hline & INV3 & .801 & .957 & \\
\hline & INV4 & .898 & .951 & \\
\hline & INV5 & .785 & .958 & \\
\hline & INV6 & .875 & .952 & \\
\hline & INV7 & .801 & .957 & \\
\hline & INV8 & .898 & .951 & \\
\hline & INV9 & .833 & .955 & \\
\hline & INV2 & .875 & .952 & \\
\hline
\end{tabular}


To statistically explore the mediating hypotheses from $\mathrm{H} 4$ to H6, the current research continued to estimate Models 2 and 3, the outcomes of which are presented in Table 4. The statistical significance for testing mediating effects was estimated following approaches proposed by Aroian (1947). As can be seen in Table 4, Models 2 and 3 are significant at the $1 \%$ value with the $\mathrm{F}$ values of 8.823 and 21.966 respectively. The values of $\mathrm{R} 2$ attain the levels of 0.263 and 0.546. In addition, the values of Durbin-Watson are 2.071 and 2.284, lying in the intervals from du to (4 $\mathrm{du}$ ); consequently, claiming no autocorrelation in Models 2 and 3. The abovementioned arguments lead to the conclusion that Models 2 and 3 get good fitness to the research data. As Table 3 reveals, CE1, CE2 and CE3 have statistical effects on BE (Model 1); while based on Table 4, CE1, CE2 and CE3 put statistical influences on INV (Model 2) that in turn imposes statistical impact on BE (Model 3).

Table 2. Correlations among independent variables $(\mathrm{N}=78)$

\begin{tabular}{cccccc}
\hline & & CE3 & CE2 & CE1 & INV \\
\hline \multirow{2}{*}{ CE3 } & Correlation & 1 & .254 & -.077 & .340 \\
& Sig. & & .025 & .503 & .002 \\
\hline \multirow{2}{*}{ CE2 } & Correlation & .254 & 1 & -.067 & .388 \\
& Sig. & .025 & & .560 & .000 \\
\hline \multirow{2}{*}{ CE1 } & Correlation & -.077 & -.067 & 1 & -.264 \\
& Sig. & .503 & .560 & & .019 \\
\hline \multirow{2}{*}{ INV } & Correlation & .340 & .388 & -.264 & 1 \\
& Sig. & .002 & .000 & .019 & \\
\hline
\end{tabular}

Table 3. Multiple regressions

\begin{tabular}{|c|c|c|c|c|}
\hline Dependent variable & Regressor & $\beta$ & $\mathrm{t}$ & Sig.(t) \\
\hline \multirow{8}{*}{ BE (Model 1) } & $\overline{\mathrm{C}_{0}}$ & .585 & 1.393 & .168 \\
\hline & CE1 & -.518 & -2.330 & .023 \\
\hline & CE2 & .391 & 4.579 & .000 \\
\hline & CE3 & .017 & 2.984 & .004 \\
\hline & $\mathrm{R}^{2}$ & & .391 & \\
\hline & $\mathrm{F}$ & & 15.843 & \\
\hline & Sig.(F) & & .000 & \\
\hline & Durbin-Watsor & & 2.263 & \\
\hline
\end{tabular}

Anchored in Model 1, CE1, CE2 and CE3 affect BE at the 5\%,1\% and 1\% significance levels with the estimates of $-0.518,0.391$ and $0.017(\beta=-0.518,0.391$ and 0.017; Sig. $(t)=0.023,0.000$ and 0.004). In Model 3, CE1 has no impact on BE (Sig. $(t)=0.187)$; whereas CE2 and CE3 influence BE at the $1 \%$ and $10 \%$ significance levels with the coefficients of 0.261 and $0.010(\beta=0.261$ and 0.010 ; Sig. $(t)=0.001$ and 0.051$)$. When entered into the research model from Model 1 to Model 3, INV makes CE1 become insignificant in Model 3 (Sig. $(t)=0.187$ ) from significant in Model 1 (Sig. $(\mathrm{t})=0.023)$, and the influential estimate also decreases to $|-0.266|$ from $|-0.518|$. The influential coefficients of CE2 and CE3 on BE decrease to 0.261 and 0.010 from 0.391 and 0.017 and simultaneously the significance levels also go up to $10 \%$ and $1 \%$ from $5 \%$ and $1 \%$. These findings suggest there may be mediating effects of INV on the causal links from CE1, CE2 and CE3 to BE. Subsequently, this research applied procedures proposed by Aroian (1947) to analyze the statistical significance for the mediating influences. The analytic procedures created the results in Table 5. As the figures reveal in Table 5, the mediating effects of INV on the causal connection from CE1, CE2 and CE3 to BE are all statistically significant at the 5\% level (Zindirect= 2.014, 2.545 and 2.101; Sig.= 0.044, 0.011 and 0.036). Overall, it can conclude that INV totally intervenes in the causal linkage between CE1 and BE, but it partially mediates in the causal relations of CE2 and CE3 to BE. These abovementioned findings indicate that, INV completely transmits the effects of CE1 on BE; whereas it only transmits a part of the impacts of CE2 and CE3 on BE. Accordingly, the abovementioned findings are in support of the hypotheses H4, H5 and H6. 
Table 4. Multiple regression analyses for mediation

\begin{tabular}{|c|c|c|c|c|}
\hline Dependent variable & Regressor & $\beta$ & $\mathrm{t}$ & Sig.(t) \\
\hline \multirow{8}{*}{ INV (Model 2) } & $\mathrm{C}_{0}$ & 1.276 & 3.023 & .003 \\
\hline & CE1 & -.501 & -2.244 & .028 \\
\hline & CE2 & .259 & 3.016 & .004 \\
\hline & CE3 & .014 & 2.361 & .021 \\
\hline & $\mathrm{R}^{2}$ & \multicolumn{3}{|c|}{.263} \\
\hline & $\mathrm{F}$ & \multicolumn{3}{|c|}{8.823} \\
\hline & Sig.(F) & \multicolumn{3}{|c|}{.000} \\
\hline & Durbin-Watson & \multicolumn{3}{|c|}{2.071} \\
\hline \multirow{9}{*}{ BE (Model 3) } & $\overline{\mathrm{C}_{0}}$ & -.056 & -.145 & .885 \\
\hline & CE1 & -.266 & -1.333 & .187 \\
\hline & CE2 & .261 & 3.319 & .001 \\
\hline & CE3 & .010 & 1.989 & .051 \\
\hline & INV & .502 & 4.995 & .000 \\
\hline & $\overline{\mathrm{R}^{2}}$ & \multicolumn{3}{|c|}{.546} \\
\hline & $\bar{F}$ & \multicolumn{3}{|c|}{21.966} \\
\hline & Sig.(F) & \multicolumn{3}{|c|}{.000} \\
\hline & Durbin-Watson & \multicolumn{3}{|c|}{2.284} \\
\hline
\end{tabular}

Table 5. Mediation analyses (Mediator: INV)

\begin{tabular}{cccc}
\hline Dependent variable & Regressor & $Z_{\text {indirect }}$ & Sig. \\
\hline \multirow{2}{*}{ BE } & CE1 & 2.014 & .044 \\
& CE2 & 2.545 & .011 \\
& CE3 & 2.101 & .036 \\
\hline
\end{tabular}

\section{Discussions and Conclusions}

Earlier studies have explored the causal link from corporate governance to organizational performance; however, to the best of our knowledge there has been only a little empirical research that analyzed on banks' corporate governance and its influence on banking performance (Muttakin \& Ullah, 2012). These studies were carried out mainly in developed nations. Recently, there is some attention to corporate governance in emerging economies (Abobakr \& Elgiziry, 2017) and very little has been considered for the banking sector, especially for Vietnam's banking sector. Furthermore, the mediating role of innovation in the research model should be taken into account. The current research seeks to examine the causal link from corporate governance to banking performance in Vietnam as a rising country. Then it attempts to analyze the mediating role of innovativeness between corporate governance to banking performance, which has been ignored in the banking sector.

The empirical findings disclose that good mechanisms of corporate governance in banking can lead to superior banking performance. The banks, in which the positions of the chairperson and chief executive officer are held by one individual, may suffer agency costs, so achieve poorer banking performance. Therefore, the banks in Vietnam should assign the positions of the chief executive officer and chairperson to two separate individuals. The results also imply that, the banks should hire more independent executives in the managerial board in order to lessen agency costs, so can get better banking performance. Moreover, the banks with larger managerial boards can improve banking performance since they have more precious business experience, knowledge, skill and social relations which could create substantial resources, so enhance banking success. The empirical results also discover that innovative activities in banking statistically interferes in the causal linkage between corporate governance and banking performance; where innovation fully interferes into the duality of the chairperson- chief executive officer and banking performance, but it partially interferes in the relations of board independence and board size with banking performance. As such, when included into the research model of corporate governance and banking performance, 
innovativeness in banking enables chief executive officer duality and banking performance to be insignificant and it also decreases the causal impacts of board independence and size on banking performance.

For the managerial knowledge, the current research provides statistical evidence that banks where the amount of independent executives in the managerial boards is dominant, the positions of chairperson and chief executive officer are separately taken by two different individuals, and higher sizes of managerial boards likely obtain better banking performance. The causal connection from corporate governance to banking performance is evidenced to be mediated by innovative activities in banking. To banking executive officers, the current study sheds an insight on the complex linkage among corporate governance, banking performance and innovation in Vietnam as a developing nation, which helps them understand comprehensively this relationship. Those can lead the banking executives to make better business decisions on the choice of good corporate governance mechanisms as well as innovative levels in banking in order to build competitive advantages in a dynamic and rapidly changing business environment in Vietnam, and consequently improve their banking performance.

\section{References}

Abdullah, H., \& Valentine, B. (2009). Fundamental and ethics theories of corporate governance. Middle Eastern Finance and Economics, 4(4), 88-96.

Abobakr, M. G. (2017). Corporate Governance and Banks Performance: Evidence from Egypt. Asian Economic and Financial Review, 7(12), 1326-1343.

Abobakr, M. G., \& Elgiziry, K. (2017). The relationship between board of directors' characteristics and bank risk-taking: Evidence from Egyptian banking sector. Journal of Finance and Accounting, 5(1), 24-33.

Abrams, F. W. (1951). Management's responsibilities in a complex world. Harvard Business Review, 29(3), 29-34.

Adams, R. B., \& Mehran, H. (2012). Bank board structure and performance: Evidence for large bank holding companies. Journal of Financial Intermediation, 21(2), 243-267.

Aroian, L. A. (1947). The probability functions of the product of two normally distributed variables. The Annals of Mathematical Statistics, 18(2), 265-271.

Balsmeier, B., Fleming, L., \& Manso, G. (2017). Independent boards and innovation. Journal of Financial Economics, 123(3), 536-557.

Baron, R. M., \& Kenny, D. A. (1986). The moderator-mediator variable distinction in social psychological research: Conceptual, strategic, and statistical considerations. Journal of Personality and Social Psychology, 51(6), 1173-1182.

Belkhir, M. (2009). Board structure, ownership structure and firm performance: evidence from banking. Applied Financial Economics, 19(19), 1581-1593.

Belloc, F. (2012). Corporate governance and innovation: A survey. Journal of Economic Surveys, 26(5), 835-864.

Blair, J., \& Conrad, F. G. (2011). Sample size for cognitive interview pretesting. Public Opinion Quarterly, 75(4), 636-658.

Blibech, N., \& Berraies, S. (2018). The impact of CEO'duality and board's size and independence on firms' innovation and financial performance. E3 Journal of Business Management and Economics, 9(1), 22-29.

Cheng, S. (2008). Board size and the variability of corporate performance. Journal of Financial Economics, 87(1), 157-176.

Chung, K. H., Wright, P., \& Kedia, B. (2003). Corporate governance and market valuation of capital and R\&D investments. Review of Financial Economics, 12(2), 161-172.

Daily, C. M., \& Dalton, D. R. (1993). Board of director's leadership and structure: Control and performance implications. Entrepreneurship Theory and Practice, 17(3), 65-81.

Dalton, C. M., \& Dalton, D. R. (2005). Boards of directors: Utilizing empirical evidence in developing practical prescriptions. British Journal of Management, 16(1), 91-97.

Darroch, J., \& Jardine, A. (2002). Combining firm-based and consumer-based perspectives to develop a new measure for innovation. Zhejiang: Zhejiang University Press, China.

Davis, J. H., Schoorman, F. D., \& Donaldson, L. (1997). Toward a stewardship theory of management. Academy of Management Review, 22(1), 20-47. 
De Andres, P., \& Vallelado, E. (2008). Corporate governance in banking: The role of the board of directors. Journal of Banking \& Finance, 32(12), 2570-2580.

Distanont, A. (2020). The role of innovation in creating a competitive advantage. Kasetsart Journal of Social Sciences, 41(1), 15-21.

Fama, E. F., \& Jensen, M. C. (1983). Separation of ownership and control. The Journal of Law and Economics, 26(2), 301-325.

Fanta, A. B., Kemal, K. S., \& Waka, Y. K. (2013). Corporate governance and impact on bank performance. Journal of Finance and Accounting, 1(1), 19-26.

Fidanoski, F., Mateska, V., \& Simeonovski, K. (2014). Corporate governance and bank performance: Evidence from Macedonia. Economic analysis, 47(1-2), 76-99.

Freeman, R., Wicks, C., \& Parmar, B. (2004). Stakeholder Theory and The Corporate Objective Revisited. Organization Science, 15(3), 364-369.

Galia, F., \& Zenou, E. (2018). Board composition and forms of innovation, does diversity make a difference?. European Journal of International Management Decision, 6(6), 630-650.

Hassan, M. U., Malik, A. A., Hasnain, A., Faiz, M. F., \& Abbas, J. (2013). Measuring employee creativity and its impact on organization innovation capability and performance in the banking sector of Pakistan. World Applied Sciences Journal, 24(7), 949-959.

Hassan, M. U., Shaukat, S., Shakeel, M., \& Imran, M. (2012). Interrelations between organizational culture, Innovation and employee performance: Evidence from banking sector of Pakistan. Pakistan Journal of Social Sciences (PJSS), 32(2), 339-355.

Jermias, J. (2007). The effects of corporate governance on the relationship between innovative efforts and performance. European Accounting Review, 16(4), 827-854.

Jiang, C., Feng, G., \& Zhang, J. (2012). Corporate governance and bank performance in China. Journal of Chinese Economic and Business Studies, 10(2), 131-146.

Johnson, J. L., Daily, C. M., \& Ellstrand, A. E. (1996). Boards of directors: A review and research agenda. Journal of Management, 22(3), 409-438.

Kang, E., \& Zardkoohi, A. (2005). Board leadership structure and firm performance. Corporate Governance: An International Review, 13(6), 785-799.

Kiel, G. C., \& Blennerhasett, P. (1984). The board of directors in large Australian companies. Management Decision, $22(1), 40-44$

Koo, K. (2019). Do not change horses: specialist CEOs enhances innovation. Technology Analysis \& Strategic Management, 31(8), 875-887.

Latif, K., Bhatti, A. A., \& Raheman, A. (2017). Earnings quality: A missing link between corporate governance and firm value. Business and Economic Review, 9(2), 255-280.

Lay Hong, T., Boon Cheong, C., \& Syaiful Rizal, H. (2016). Service Innovation in Malaysian Banking Industry towards Sustainable Competitive Advantage through Environmentally and Socially Practices. Procedia - Social and Behavioral Sciences, 224, 52-59.

Lipton, M., \& Lorsch, J. W. (1992). A modest proposal for improved corporate governance. Business Lawyer, 48(1), 59-77.

McDonald, D., \& Puxty, A. (1979). An Inducement - Contribution Approach to Corporate Financial Reporting. Accounting, Organization and Society, 4(1/2), 53-65.

Miozzo, M., \& Dewick, P. (2002). Building competitive advantage: innovation and corporate governance in European construction. Research Policy, 31(6), 989-1008.

Muttakin, M. B., \& Ullah, S. (2012). Corporate governance and bank performance: Evidence from Bangladesh. Corporate Board: Role, Duties \& Composition, 8(1), 62-68.

Naushad, M., \& Malik, S. A. (2015). Corporate governance and bank performance: a study of selected banks in GCC region. Asian Social Science, 11(9), 226-234.

Nawaz Khan, S., Hussain, R. I., -Ur-Rehman, S., Maqbool, M. Q., Engku Ali, E. I., \& Numan, M. (2019). The 
mediating role of innovation between corporate governance and organizational performance: Moderating role of innovative culture in Pakistan textile sector. Cogent Business \& Management, 6(1), 1631018.

Nunnally J. C. (1978). Psychometric Theory. New York: McGraw-Hill, USA.

Owino, B., \& Kivoi, D. L. (2016). Corporate governance and bank performance: A case of Kenya's banking sector. Journal of Research in Humanities and Social Science, 1(1), 33-46.

Parasuraman, A. (2010). Service productivity, quality and innovation: Implications for service-design practice and research. International Journal of Quality and Service Sciences, 2(3), 277-286.

Pi, L., \& Timme, S. G. (1993). Corporate control and bank efficiency. Journal of Banking \& Finance, 17(2-3), 515-530.

Rishi, M., \& Saxena, S. C. (2004) Technological innovations in the Indian banking industry: the late bloomer. Accounting, Business \& Financial History, 14(3), 339-353.

Sadikoglu, E., \& Zehir, C. (2010). Investigating the effects of innovation and employee performance on the relationship between total quality management practices and firm performance: An empirical study of Turkish firms. International Journal of Production Economics, 127(1), 13-26.

Sanda, A., Mukaila, A., \& Garba, T. (2005). Corporate Governance Mechanisms and Firm Financial Performance in Nigeria, AERC Research Paper 149. African Economic Research Consortium, Nairobi.

Sarkar, S. S. (2016). Technological innovations in Indian banking sector-a trend analysis. Journal of Commerce and Management Thought, 7(1), 171-185.

Schumpeter, J. A. (1934). The Theory of Economic Development. Cambridge, MA: Harvard University Press, USA.

Schumpeter, J. A. (1942). Capitalism, Socialism and Democracy. New York: Harper and Row, USA.

Setia-Atmaja, L., Tanewski, G. A., \& Skully, M. (2009). The role of dividends, debt and board structure in the governance of family controlled firms. Journal of Business Finance \& Accounting, 36(7-8), 863-898.

Shet, A. R. (2016). Technological Innovations in Indian Banking Sector. International Journal of Scientific Engineering and Research, 4(5), 11-14.

Shleifer, A., \& Vishny, R. W. (1997). A survey of corporate governance. Journal of finance, 52(2), 737-783.

Singh, J. (2008). Distributed R\&D, cross-regional knowledge integration and quality of innovative output. Research Policy, 37(1), 77-96.

Tomar, S., \& Bino, A. (2012). Corporate governance and bank performance: evidence from Jordanian banking industry. Jordan Journal of Business Administration, 153(655), 1-40.

Vaccaro, A., Parente, R., \& Veloso, F. M. (2010). Knowledge management tools, inter-organizational relationships, innovation and firm performance. Technological Forecasting and Social Change, 77(7), 1076-1089.

Wang, D. H. M., \& Huynh, Q. L. (2014). Linkages among corporate governance, management accounting practice and organizational performance: Evidence from a Southeast Asian country. Romanian Economic and Business Review, 9(1), 63-81.

Wheelen, T. L., Hunger, J. D., Hoffman, A. N., \& Bamford, C. E. (2010). Strategic management and business policy. Upper Saddle River, NJ: Prentice Hall, USA.

\section{Copyrights}

Copyright for this article is retained by the author(s), with first publication rights granted to the journal.

This is an open-access article distributed under the terms and conditions of the Creative Commons Attribution license (http://creativecommons.org/licenses/by/4.0/). 